\title{
O Domínio do Homem pelo Homem na Novela $A$ Senhoria, de Dostoiévski ${ }^{1}$
}

Fátima Bianchi

\begin{abstract}
This article deals with the theme of alienation, in the sense of the subjugation of one person by another, that in the novella The Landlady appears as the moral domination of a woman by her husband. In his quest for a verisimilar representation of this question, which was taken with great perspicacity from contemporary life, Dostoevsky found an original perspective that reflected the great difficulty, indeed, the incapacity, of both of the characters, as well as the narrator, to apprehend existence in its totality.
\end{abstract}

Keywords: Dostoevsky; The Landlady; Russian literature.

Resumo: Este trabalho trata do tema da alienação, no sentido da subjugação de um ser humano por outro, que na novela $A$ Senhoria se revela no domínio moral da mulher pelo marido. Na busca de uma representação verossímil dessa questão, extraída com grande capacidade de clarividência da realidade da época, Dostoiévski encontra uma perspectiva inédita, capaz de refletir toda a dificuldade, ou mesmo incapacidade, tanto do narrador como das personagens, de apreender a existência em sua totalidade.

Palavras-chave: Dostoiévski; A Senhoria; literatura russa.

Como em todo grande escritor, as situações ficcionais que Dostoiévski expõe mesmo em suas primeiras obras, então terminantemente rejeitadas pela grande maioria dos críticos, sempre ocultaram algo até mesmo dos leitores mais atentos. É o que acontece com sua novela $A$ Senhoria, publicada em 1847, na revista Anais Pátrios

\footnotetext{
${ }^{1}$ Este artigo foi originalmente publicado em russo, no livro Dostoiévski: Filosofskoe Michlenie, Vzgliad Pisatelia (O pensamento filosófico e o ponto de vista do escritor), no volume III da série "Dostoevsky Monografs" (publicação da International Dostoevsky Society). Para a presente publicação, o texto foi revisado e ampliado.

${ }^{2}$ Professora Doutora da área de Língua e Literatura Russa do Departamento de Letras Orientais da Faculdade de Filosofia, Letras e Ciências Humanas da Universidade de São Paulo, coordenadora regional da International Dostoevsky Society e presidente de sua seção brasileira. E-mail: fbianchi@usp.br.
} 
(Otetchiéstvienie Zapiski), cujos comentários na época arrasaram com as expectativas que o autor nela depositara para sua carreira literária.

Belínski, ao perceber na história uma enorme incongruência temática e estilística, descreveu-a como "uma tremenda besteira". Sem esconder sua decepção, declarou que "não só a idéia, como também o sentido dessa novela, que talvez seja até interessante, continuará oculto à nossa compreensão se o autor não emitir os esclarecimentos necessários a esse enigma surpreendente da sua fantasia mirabolante" (Belínski, 1948, p. 837). Influenciada pelo crítico, essa opinião sobre $A$ Senhoria perdurou por pelo menos meio século.

O porquê da rejeição a essa novela pode ser explicado pelo contexto sociocultural da época de sua criação, em que o valor e o significado de uma obra dependiam em muito de ela exprimir ou não algum aspecto da realidade. E Dostoiévski, ao envolvê-la numa atmosfera aparentemente sobrenatural, de mistério, cria uma dificuldade para o leitor e, na opinião de Belínski, se desvia da "via comum" e "busca para si um caminho inédito qualquer" (Belínski, 1948, p. 837).

Hoje podemos perceber que a dificuldade criada à sua compreensão faz parte da própria modalidade de construção da narrativa, que reflete a temática nela abordada. Como, na concepção de Dostoiévski, "a tarefa da arte não é a casualidade da vida, mas o total da idéia dela" (Dostoiévski, 1972, p. 82), suas buscas na literatura se deram em estreita unidade com as questões mais profundas sobre o sentido da vida, já que o artista, para ele, devia buscar na realidade não aquilo que era conjuntural, transitório, mas uma marca da situação do mundo, da época como um todo. Daí sua recusa à tarefa de representar a realidade "tal como ela é", imposta aos escritores ligados à então chamada escola natural, de orientação realista, da qual Belínski se destacava como o grande ideólogo.

Na opinião de Dostoiévski, "uma tal realidade não existia absolutamente, nem nunca existira na face da terra, porque a essência das coisas não é acessível ao homem, 
que percebe a natureza da forma como ela se reflete em sua idéia, passando por seus sentimentos" (Dostoiévski, 1972, p. 75). Sendo assim, ele entendia que o grande desafio que estava colocado na ordem do dia para os escritores era como representar a essência da vida num mundo que se tornara cada vez mais complexo, fragmentado, e no qual o próprio herói desconhecia o caminho que teria de percorrer.

A consciência aguda de que já não era mais possível uma narração da perspectiva "privilegiada" de um narrador que impõe ao mundo seu ponto de vista, uma vez que as próprias bases dessa atitude assumida por ele se achavam comprometidas pela realidade objetiva, o levou a adotar, em seu romance de estreia, Gente Pobre, a forma epistolar sem nenhuma interferência autoral. Com esse recurso, ele deixa completamente a cargo da personagem a tarefa de conduzir a narrativa sobre si mesma e o mundo que a rodeia a partir de seu próprio ponto de vista.

Já na novela $A$ Senhoria, na busca da representação verossímil de questões extraídas, com grande capacidade de clarividência, da realidade da época, ele encontra uma perspectiva inédita, capaz de refletir toda a dificuldade, ou mesmo incapacidade, tanto do narrador como das personagens, de apreender a existência de modo total. E, embora não tenha sido compreendida por seus contemporâneos, que viram nela o mais completo afastamento de seu autor da tendência de orientação realista, ela apresenta uma certa dimensão social, que tem passado despercebida, e que se faz necessário apontar, a fim de penetrar em seu significado.

Trata-se do tema da alienação, no sentido da subjugação de um ser humano por outro, que na novela adquire a forma de domínio moral da mulher pelo marido. De acordo com o Novo Dicionário Aurélio, o termo "alienação", num sentido filosófico, se refere a um:

processo ligado essencialmente à ação, à consciência e à situação dos homens, e pelo qual se oculta ou se falsifica essa ligação de modo que apareça o processo (e seus produtos) como indiferente, independente ou superior aos homens, seus criadores (Ferreira, p. 69). 
Com base nessa acepção, procuramos mostrar que a representação desse tema na obra está toda voltada para o seu desmascaramento, com o propósito de desvendar o tipo de relação social oculta pelo processo da alienação, que, ao mesmo tempo, desumaniza não só a pessoa oprimida como também o opressor.

O crítico soviético A.L. Bem, num ensaio escrito nos anos 1920 ("Dostoiévski um Leitor Genial"), dedicado à novela $A$ Senhoria, afirma que, para Dostoiévski, o poder de Múrin sobre a esposa, Katierina:

se explica pela psicologia do 'coração fraco', de um estado psíquico especial em que o homem se vê pronto a entregar voluntariamente a sua liberdade a outro apenas pelo fato de ele tomar para si toda a responsabilidade por ele, pelo direito de passar a sua culpa, de seus ombros frágeis, para os ombros de outra pessoa" (Bem, 2001, p. 32).

De certa forma, Bem tem razão, e esta é a mesma explicação de Múrin para o que ele chama de alienação mental de Katierina. Mas o que Bem, assim como Múrin, não explicam é como e por que ela, de autêntica "filha da natureza", se tornara um "coração fraco". Pela maneira como Dostoiévski elabora artisticamente o seu material, o tema da subjugação de um homem por outro na obra acaba por trazer à tona que "a escravização da vontade, a entrega de si mesma ao poder de outro", ao contrário do que afirma Bem, não se dá absolutamente "de forma voluntária", mas por meio de um processo que envolve "uma tirania profunda e implacável". E é exatamente isso o que Múrin tem necessidade de ocultar com a sua explicação sobre a situação de Katierina, mas que acaba transparecendo na narrativa dela, ao contar sua história a Ordínov, que se apaixonara por ela à primeira vista.

Em seu objetivo último de penetrar naquilo que realmente constitui o verdadeiro significado da existência, Dostoiévski construiu toda a novela a partir de um tipo de situação armada numa cena inicial em que Múrin lança um olhar desafiador a Ordínov. 
Com a repetição desse motivo do olhar em várias ocasiões, que serviu a Belínski como motivo de ironia, ${ }^{3}$ o autor de certa forma estabelece uma espécie de duelo velado entre ambos pelo coração da jovem.

Desde essa cena inicial, que tem lugar numa igreja, onde se dá o primeiro encontro dos três, o leitor é imediatamente atraído pela sensação de uma atmosfera de mistério impenetrável em torno do estranho casal Katierina e Múrin, que se estende por toda a narrativa. Ela, aos olhos de Ordínov uma jovem de beleza celestial, é apresentada pelo marido como uma mulher do povo, "uma moça simplória, uma roceira mal-lavada, uma caipira estúpida" (Dostoiévski, 2006, p. 108); já ele aparece como um comerciante que goza do status de autoridade por seus poderes aparentemente sobrenaturais.

Conhecido por todos como feiticeiro, Múrin parece ocultar um segredo. Ora, a ideia que temos do segredo, a menos que seja de polichinelo, é de uma coisa misteriosa, impenetrável, que não se divulga, e conhecida apenas de alguns poucos. Pode ser também um meio de que se serve uma pessoa para tornar-se superior às outras com o resultado obtido. E o que a narrativa se propõe é justamente a revelação de algo secreto, que se oculta à vista, ao conhecimento, e que dá a seu portador, Múrin, um poder excepcional.

Pode-se dizer então que na novela há um desafio posto à sua interpretação, que tem a ver com a maneira como a narrativa foi construída, que se revela naquilo que ela oculta: o segredo de Múrin para a alienação de Katierina. E, como será mostrado adiante, nisso consiste toda a sua fundamentação ideológica, que, como observou Bem, só é desvendada no final, quando o domínio que ele exerce sobre ela se revela nitidamente como a prova mais cabal da sua teoria de que a liberdade, para o homem fraco, constitui um fardo. Dostoiévski procura mostrar, no entanto, que ser "fraco" não é algo que está na natureza da pessoa, que faz parte de sua índole, mas o resultado do condicionamento a que ela fora submetida.

\footnotetext{
${ }^{3}$ Belínski diz: "Nos olhos dele havia tanta eletricidade, galvanismo, magnetismo, que qualquer fisiologista lhe proporia um bom preço para abastecer de tempos em tempos suas experiências e observações científicas, se não com os olhos, pelo menos com seus olhares fulminantes e faiscantes” (Belínski, 1947, p. 837).
} 
A ação em $A$ Senhoria, assim como em todas as obras anteriores do escritor, tem lugar em Petersburgo. Mas, em seu centro, no lugar do funcionário pobre, ele situa um outro tipo, psicologicamente mais complexo: a figura de um jovem idealista, de origem nobre, que acaba por se revelar como mais um dos heróis então em evidência: o "homem supérfluo".

No entanto, o fato de a novela estar toda envolvida por um forte clima de mistério, levou Bem a uma interpretação bastante questionável a respeito de suas personagens centrais, que exerceu uma influência considerável sobre a crítica. Para ele, o verdadeiro herói de $A$ Senhoria é Ordínov, “apenas e unicamente ele” (Bem, 2001, p. 322), enquanto Katierina, Múrin e as demais personagens seriam fruto de sua imaginação, "uma generalização artística do conflito interior na alma de Ordínov, apenas um símbolo que revela um certo 'mistério de seu mundo interior'” (Bem, 2001, p. 286).

Entre a crítica mais recente, Victor Terras pondera que Ordínov só poderia ser considerado o herói da novela

se o todo ou a maior parte da ação fosse entendida como um produto das alucinações de Ordínov, no sentido em que o é a novela expressionista. Caso contrário, ele é apenas um espectador, um "simulacro" do narrador, através do qual tomamos conhecimento do estranho e excitante casal Múrin e Katierina (Terras, 1969, p. 196).

Já Josef Frank afirma que Katierina é a personagem central, uma vez que o foco narrativo, como indicado no título da novela, incide sobre ela e sua relação com Múrin e Ordínov (Frank, 1999, p. 438).

Ainda que Katierina e Múrin ocupem um lugar de grande destaque na trama, não há dúvida de que seu tema central é o tipo "sonhador” e Ordínov, sua personagem principal. E o mistério que envolve toda a narrativa não está absolutamente em seu mundo interior, como procurou demonstrar Bem, mas na realidade que cerca Múrin e coloca Katierina sob seu poder. No entanto, só a possibilidade de tal interpretação já seria 
suficiente para nos levar a desconfiar até mesmo do papel do narrador, que, voluntariamente ou não, parece encobrir algo muito importante. Outro indício disso é que a narrativa de Katierina a Ordínov sobre a sua vida, sobre como ela fugiu e amigou-se com o assassino de seus pais, é interrompida por duas vezes em momentos-chave para o desvendamento do enigma em torno da figura de Múrin e não é mais retomada.

Nesse sentido, a forma escolhida para contar a história desempenha um papel fundamental. A narrativa está concentrada no momento presente dos acontecimentos e é conduzida por um narrador externo, a partir de um centro fixo, que é Ordínov - uma figura "exageradamente suscetível", "cheia de entusiasmos juvenis", mas "totalmente incapacitada para a vida prática". Afetado pela ideia de que não sabe tudo, pela própria precariedade de nossa capacidade de percepção, o narrador só toma conhecimento daquilo que entra para o campo de visão e a mente de Ordínov, o que torna seu objeto parcial e sua perspectiva, extremamente limitada.

Uma narração de um ponto de vista onisciente e distanciado impediria a representação de um tema essencial dessa obra, que é a questão da identidade, do enigma de uma personalidade, do aspecto da divisão do ser na sociedade moderna. Tema este que se evidencia na narrativa de Katierina, em que ela se apresenta como uma jovem de uma região longínqua do Volga, que crescera livre pelos bosques, entre barqueiros e operários; um mundo em que a existência era compreendida em sua totalidade e os caminhos a seguir já estavam traçados para o homem. Não por acaso ela diz que era a noiva prometida de Aliósha “desde seu nascimento".

Mas ela é seduzida por um ser diabólico, representado pela figura de um comerciante atraente, astucioso, enigmático e ao mesmo tempo sem escrúpulos, que se utiliza de todos os meios para conseguir os fins a que se propõe. E é significativo que esse ser diabólico, que na calada da noite ousa penetrar em "seu quartinho de solteira" e corromper sua alma, já houvesse feito o mesmo com sua mãe, quando aparecia em sua casa para vender suas mercadorias, e provavelmente seja seu pai. 
Acostumada desde a infância a vê-lo como a própria encarnação do mal, a princípio Katierina esboça uma luta contra ele. E o primeiro indício de sua rendição transparece quando ela aceita as pérolas que ele lhe oferece, uma mercadoria preciosa e sedutora, com o intuito, num primeiro instante, de desafiar a mãe. Com isso se fecha o círculo da discórdia lançada pelo comerciante no seio de sua família.

É muito expressivo, ainda, que esse homem que arrasa com o mundo de Katierina, com seus pais, sua casa, seu noivo prometido, e leva consigo um rastro de destruição do antigo mundo por onde passa, se apresente a Ordínov como "burguês". Também não deve ser por acaso que ele surja no delírio de Ordínov como sendo o mesmo velho que fez desabar o mundo de ordem e completa satisfação de sua infância, promovendo uma espécie de fragmentação da própria unidade paradisíaca original. Com a sua aparição, no lugar dos espíritos luminosos que enxameavam em redor de seu berço, trazendo harmonia e sentido a tudo à sua volta, Ordínov vê abrir-se diante de si um abismo, que representa uma cisão em seu mundo.

O que se pode conjeturar é que sua família fora arruinada pelas novas relações que estavam se desenvolvendo na sociedade russa com a introdução do capitalismo. E isso é bem possível, tanto que nas vidas de Katierina e Ordínov parece haver uma simetria especular. A fratura em seus mundos parece ter uma mesma origem. Nesse caso, a figura de Múrin poderia então ser interpretada como uma representação simbólica dessa nova ordem.

E se, após o encontro na igreja, as vidas de Ordínov e Katierina se entrelaçam, é porque há uma convergência também em suas buscas. Ele, apresentado na novela como um tipo intelectual idealista, está se dedicando ao estudo de um sistema provavelmente relacionado com a necessidade de resolver a questão histórica que sempre afligiu a humanidade - a "escravização" dos fracos pelos fortes -, enquanto ela apresenta estampado no rosto o sofrimento do povo. Um povo que Ordínov, em sua origem nobre, “conhece de ouvir falar”, mas não conhece na realidade. 
Ela anseia pela vinda de seu libertador. E, ao ver Ordínov plantado à sua porta como que encarnando um papel de herói, logo o toma pelo "hóspede esperado" de sua casa.

O crítico Rudolf Neuhauser, num ensaio de 1968 sobre $A$ Senhoria, seguindo uma interpretação manifestada já por contemporâneos de Dostoiévski, toma o encontro de Katierina e Ordínov na igreja como "um encontro entre a intelligentsia e o povo" (Neuhauser, 1968, p. 54). ${ }^{4}$ Neuhauser sugere que Katierina, que "representa o povo russo, a alma russa", entendeu o passo de Ordínov, "um intelectual progressista, ocidentalista", ao vê-lo à sua porta, e "está preparada a unir forças com ele e resistir a Múrin" (Neuhauser, 1968, p. 49), "personificação de todo o mal nas tradições nacionais da Rússia, particularmente como concentrada nos rituais religiosos" (Neuhauser, 1968, p. $50)$.

Embora Katierina se mostre pronta a se rebelar, Múrin, que se considera o "único feiticeiro" de "seu coraçãozinho de ouro" (Dostoiévski, 2006, p. 97), tem os seus meios para mantê-la cativa. É importante notar que essa denominação de feiticeiro não é nada casual. O feiticeiro é um bruxo, um mago, é alguém que faz feitiços. Num sentido figurativo, é um homem que atrai, encanta, agrada, cativa a amizade dos outros, enfim, que enfeitiça. E, nesse assunto, pode-se dizer que Múrin é especialista. Entendido nas letras divinas e humanas, a essência de sua estratégia para o condicionamento e a submissão de Katierina está fundamentada em sua concepção de que a liberdade, para o "homem fraco", é um fardo, do qual ele é capaz de tudo para se livrar.

Ele sabe que, na imaginação dela, "a liberdade é mais saborosa que o pão, mais esplêndida que o sol" (Dostoiévski, 2006, p. 31). Seu segredo, portanto, consiste em saber manter nela a ilusão de que é livre, já que, na sua interpretação da conduta humana,

\footnotetext{
${ }^{4}$ Já antes o crítico e amigo de Dostoiévski N. N. Strákhov havia observado que em A Senhoria pela primeira vez Dostoiévski tocara em um tema importante para a sua obra, que se refere à relação entre o "sonhador" intelectual e o povo, que ocupa um lugar central em suas obras dos anos de 1860-1870 (Apud. Grossman, O Caminho de Dostoiévski, p. 72-74).
} 
o importante não é o que existe na realidade, mas o que existe na imaginação da pessoa.

Portanto, abrir a porta de sua casa e permitir que Ordínov nela se instale, para não contrariar Katierina, faz parte de seu estratagema para o domínio da alma livre dela, cujo processo tem início quando a leva da casa de seus pais com a promessa de jamais tolher sua liberdade. Seu pacto com Katierina nesse momento é selado com uma promessa: "se vier a deixar de me amar... eu lhe restituirei seu amor com sua liberdadezinha dourada; só que nesse instante, minha bela orgulhosa, intolerante, terá fim também a minha vida!" (Dostoiévski, 2006, p. 77). Isso é o que ele lhe diz, transmitindo-lhe a ideia de uma inversão dos papéis, como se fosse ele seu escravo. O que ele faz, no entanto, é exatamente o contrário. Mas ele o faz com muita arte e com muita astúcia, ao empregar, em sua presença, a mesma linguagem poética que ela, e ao relembrá-la de seu juramento sempre que surge a necessidade de reforçar seu domínio sobre ela ou dele tirar proveito.

$\mathrm{Na}$ repetição ostensiva de que ela é livre como um pássaro, associada a falsas demonstrações de que será um eterno escravo de seus desejos, até Katierina assimilá-la a ponto de se entorpecer, revela-se todo o processo com que Múrin mascara para ela o real e vai moldando o seu comportamento e tomando conta da sua subjetividade, até eliminá-la. Nos mínimos detalhes, cada palavra, cada gesto seu é extremamente calculado, no sentido de dar continuidade ao processo de alienação de Katierina, desenvolvido em várias etapas, até torná-lo completamente irreversível.

Embora lhe prometesse devolver sua "liberdade dourada", caso ela deixasse de amá-lo, e simulasse a satisfação de todos os seus desejos, a ela não escapava que era "sua escrava desonrada" (Dostoiévski, 2006, p. 78), expressão empregada por ela mesma. A ideia de que a "escrava desonrada" havia substituído a "filha da natureza" não lhe é estranha. A questão é que essa consciência não viera imediatamente, mas com o tempo, quando disso, de sua vergonha, paradoxalmente, seu coração passara a tirar prazer. Daí Múrin dizer que ela "persegue a liberdade, mas nem ela mesma sabe com que se encapricha seu coração. E daí resulta que é melhor deixar tudo como estava" 
(Dostoiévski, 2006, p. 112).

Segundo palavras dele próprio a Ordínov, o segredo para a boa convivência, para infundir respeito e consideração, depende da capacidade do indivíduo de inculcar nos outros a opinião de uma qualidade que eles não possuem. Consiste na arte de saber engabelar, de mascarar a realidade, para dar a ver aquilo que não é e encobrir aquilo que é. E, se desfruta da fama de ser um homem respeitável, digno, e tem por todo lado pessoas que se curvam a ele, é porque sabe usar bem essa arte para influir no ânimo delas. Múrin não é absolutamente o que todos acreditam que ele seja. Ele é uma mentira, uma fraude, um cínico moral, que se faz passar por beato, mas despreza qualquer concepção sobre o bem e o mal.

Quando mais jovem, ele havia atraído Katierina com o seu poder de sedução. Quando já está bem mais velho, doente, para mantê-la a seu lado, começa a lançar mão de um outro instrumento, tão ou mais poderoso: a religião. E se utiliza justamente do que havia de mais irracional na cultura popular religiosa russa, de uma religião do medo, de um Deus ameaçador, que não perdoa. Depois de convencê-la de que também tinha culpa na morte dos pais, ele a obriga a se penitenciar com ele, por seus crimes, com rezas, e a mantém sob seu domínio a custo de expedientes os mais abjetos. Ela vive sob o terror de sua ameaça de voltar depois de morto atrás de sua alma pecadora, que está convencida de ter vendido a ele.

Não por acaso, na opinião de Bem, nessa novela "pode-se ver um protesto simbolicamente velado de Dostoiévski contra a Igreja em si” (Bem, 2001, p. 322). De fato, a religião, que ocupa tanto espaço em toda a extensão da obra, desempenha um papel social simbólico essencial para a fórmula do "coração fraco". Pois, certamente, não deve ser por acaso que o encontro de Ordínov com Katierina e Múrin, "entre a intelligentsia e o povo", se dá em uma igreja.

A casa de Múrin e Katierina, decorada com imagens de Nossa Senhora e lamparinas acesas por todos os cantos, como observou Diláktorskaia, funciona como uma 
extensão da igreja (Diláktorskaia, 1999). Ajoelhada diante dessas imagens, o medo mantém Katierina "o tempo todo acordada", se penitenciando com rezas. É por meio desses símbolos religiosos e com leituras de "coisas ameaçadoras, severas", dos livros sagrados dos antigos crentes, que ele a "engabela" e a submete a si. Sua aparência, seus trajes, tudo o identifica na novela como um portador de antigas tradições nacionais, folclóricas e religiosas, então ainda vivas no imaginário popular.

E, na história contada por Katierina, ele aparece como um ser diabólico, um corruptor, bandido, mas também como uma criatura excepcional. Sua palavra exerce sobre ela um poder incompreensível, que, ao mesmo tempo, aplaca e fomenta o seu medo. Como ela própria reconhece, "só com suas palavras, ele me enfeitiça" (Dostoiévski, 2006, p. 66).

Revela-se, portanto, extremamente significativo o fato de que Ordínov, que aparece à sua porta como seu libertador, estivesse se dedicando a uma "criação em que, nas horas de pausa criativa, baseava as mais concretas esperanças" (Dostoiévski, 2006, p. 116), uma história da Igreja. É importante notar que o narrador fala em "esperanças concretas". Se relacionarmos isso com o que ele diz no início da novela, que "ele estava criando seu próprio sistema" e que sua ideia já se insurgia "materializada em uma forma nova, iluminada", mas que o "momento de sua encarnação e criação ainda estava distante... talvez ela fosse absolutamente irrealizável" (Dostoiévski, 2006, p. 12), a noção de que esse "sistema" estivesse relacionado com as teorias do socialismo utópico se torna ainda mais evidente. Se for assim, o jovem de alma "pura e transparente", que Katierina reconhece ao primeiro olhar como "o hóspede de sua casa", revela-se realmente um intelectual progressista, ocidentalista.

Josef Frank, que vê Ordínov mais como "um protótipo do tipo 'sonhador' idealista romântico fora de moda", questiona essa interpretação que o aproxima dos socialistas utópicos. Seu argumento é que, nesse caso, "não se pode compreender por que Dostoiévski insistiu tanto no isolamento de Ordínov e na sua sensação de afastamento das 
outras pessoas e da vida agitada de São Petersburgo" (Frank, 1999, p. 431). No entanto, é justamente em seu isolamento que se encontra a gênese da tragédia de Ordínov, que Neuhauser, ao interpretar A Senhoria como uma alegoria sociocultural que reflete o cenário intelectual dos anos de 1846-1847, relaciona com a "tragédia do pensador socialista utópico que concentra todo o seu talento artístico e científico em filosofizações abstratas e deixa a vida passar" (Neuhauser, 1968, p. 48).

Mas Josef Frank não deixa de ter razão em considerar Ordínov um "sonhador" romântico fora de moda. Também pelas declarações de Belínski sobre a novela, Ordínov seria mais um dos "remanescentes" do idealismo romântico, motivo determinante de sua repulsa a essa obra de Dostoiévski, num momento em que o crítico se empenhava para que a literatura se tornasse, finalmente, um órgão de consciência social. A questão é que, ao colocar essa figura no centro de sua obra e mostrá-la como um tipo ainda corrente na época, o objetivo de Dostoiévski não é a sua representação pura e simplesmente como um tipo romântico, tanto que toda a ação tem como pano de fundo a realidade apresentada no nível do "ensaio fisiológico".

Ao se aprofundar em sua psicologia em busca de suas bases de sustentação na sociedade dos anos 1840, Dostoiévski promove uma reestruturação completa no modo de representação desse tipo, mostrando-o como algo estreitamente vinculado ao "homem supérfluo", o "herói de seu tempo". Todos os heróis dessa geração sentem que foram altamente predestinados, sentem na alma uma força extraordinária, mas, assim como Petchórin, ${ }^{5}$ não conseguem adivinhar em que consiste essa predestinação. Ordínov mesmo, que passou quase três anos em completo isolamento, dedicando-se a desenvolver seus conhecimentos, pelo que tudo indica relacionados com a questão da justiça social, "talvez estivesse predestinado" a realizar alguma "ideia integral, original, autêntica", "a ser um artista na ciência” (Dostoiévski, 2006, p. 116), como diz o narrador. Mas, em sua primeira tentativa de "se introduzir de algum modo nessa vida que lhe era alheia", a vida

\footnotetext{
${ }^{5}$ Personagem do romance O Herói do Nosso Tempo, de Liérmontov.
} 
viva, fora das paredes de seu quarto, e deparar com a esfera "da atividade prática, cotidiana" (Dostoiévski, 2006, p. 11), entra num beco sem saída.

De modo que, pela forma como a disputa entre Ordínov e Múrin está posta, o que está em questão nessa novela, certamente, são os fins a que ela serve: a representação e, ao mesmo tempo, o desmascaramento do "sonhador" idealista, que, na literatura romântica dos anos de 1820-1830, se distinguia por seu caráter elevado e titânico. Não por acaso, o "duelo" de olhares que se trava entre Ordínov e Múrin desde o primeiro instante adquire uma dimensão extraordinária, que no final levará ao desmascaramento da personagem e à revelação de sua verdadeira situação.

De um lado está Múrin, um velho crente, adepto da antiga religião do medo e da danação eterna, das tradições nacionais e religiosas, da velha Rússia. Do outro lado, Ordínov, um historiador da Igreja, cuja ideia, materializada numa "forma nova, iluminada", certamente estava relacionada com o "novo cristianismo" do socialismo utópico, com a ideia de libertação da "alma" russa de séculos de condicionamento, enfim, com uma nova Rússia. Entretanto, enquanto o primeiro se mostra capaz de lançar mão de qualquer expediente para conquistar a simpatia do "povo" (simbolicamente representado na novela por Katierina e todas as outras personagens, que o olham com respeito e admiração até o fim) e preservar o seu poder sobre ele, o segundo, o intelectual russo, só é capaz de conquistá-la num primeiro momento. Quando vem à tona a sua verdadeira natureza, a sua inércia e impotência para lutar por seus ideais de justiça e liberdade, ele perde o respeito e a consideração que havia despertado em todos ao primeiro olhar.

E Katierina, apesar de ser a principal fonte por meio da qual vamos conhecendo Múrin, não consegue penetrar na essência daquilo que ela mesma sabe sobre ele e perceber em seus atos e palavras os subterfúgios que ele usa para mantê-la a seu lado. Seus verdadeiros propósitos permanecem inacessíveis a ela até o fim, assim como a todos os outros envolvidos na trama, com exceção de Ordínov. 
Com sua astúcia, Múrin fora eliminando em sua imaginação aquilo que ela sabe ser a verdade, fato após fato. E o conhecimento que ela consegue ter de si mesma consiste apenas em um acúmulo de fragmentos de informações arbitrariamente abstraídos, mas que jamais a levarão à verdadeira compreensão da sua real condição. Condicionada pela situação objetiva, a sua capacidade de percepção, de conceber alternativas possíveis para a sua vida, logo alcança seus limites naturais, pois a modelagem do homem pelo homem, do indivíduo pela sociedade, pelo meio, aparece nessa novela de uma forma simbólica contundente.

Neuhauser, que associa a figura de Katierina à "alma russa escravizada por séculos de tradições religiosas e nacionais", vê sua impotência "para renunciar às tradições opressivas, para seguir o intelectual 'ocidentalista, progressista', no fato de que a compreensão da própria pessoa injuriada e humilhada se torna um tipo de ópium que conforta o homem" (Neuhauser, 1968, p. 57).

Essa é a mesma ideia emitida por Múrin sobre o peso que constitui para o homem a liberdade, em vista da necessidade objetiva: "Dê a ele, ao homem fraco, a liberdade ele mesmo a atará e a trará de volta. A um coração tolo, a liberdade de nada serve!’. Ou seja, em sua impotência para renunciar às tradições opressoras, a liberdade, para o “coração fraco", se torna mesmo um fardo.

Ao mostrar Katierina como um "coração fraco", Dostoiévski não faz senão apresentar uma situação corrente na sociedade, em que os fortes deste mundo tomam para si a "responsabilidade" pelos fracos. E como, em termos humanos, não é mais possível existir nenhum conteúdo que seja compreensível por si mesmo, para mostrar que o domínio de um homem por outro não pode ser uma coisa natural, Dostoiévski teve de buscar um meio de romper com a aparência da relação que une Katierina a Múrin. E a forma que ele encontrou para fazer isso foi apresentando Katierina, antes de se ligar a ele, como uma "filha da natureza". Ou seja, ele pegou um elemento ainda não totalmente enquadrado pela cultura e foi gradativamente descobrindo, tirando os véus que encobriam 
todo o processo de dominação a que ela fora submetida, até se tornar uma "escrava desonrada".

Quer dizer, Dostoiévski coloca Katierina como uma "filha da natureza" para mostrar que o que parece natural, a "responsabilidade", a subjugação dos fracos pelos fortes, não é uma coisa natural, mas cultural, que foi socialmente construída, à revelia. E com isso ele mostra, também, o quanto é moralmente abjeto o empreendimento de moldar a mente e a vida de um ser humano em direção a um determinado fim. Não é à toa que Múrin aparece na novela como sinônimo de cinismo, como a própria face do disfarce, e seu segredo seja o segredo da hipocrisia.

E, para desvendar esse segredo, Dostoiévski coloca no caminho de Múrin e Katierina um intelectual idealista, progressista, que, mesmo incapacitado para a ação no mundo exterior - o que em parte tem raízes na posição social e no desenvolvimento moral e intelectual da juventude russa de sua classe na época -, possui um forte senso de realidade. Tanto que, no final, o domínio que Múrin exerce sobre Katierina revela-se nitidamente a Ordínov como resultado de um poder que nada tem de sobrenatural, mas de atitudes muito bem calculadas

É verdade que o próprio Ordínov contribui desde o início para a disseminação da atmosfera de mistério que envolve a figura de Múrin. Desde o primeiro encontro ele lhe transmite uma impressão penosa: "sem saber por que, lhe fazia mal olhar para esse velho" (Dostoiévski, 2006, p. 28). Como a história de Múrin é contada de diferentes pontos de vista, tanto a narrativa do zelador tártaro como a de Iaroslav Ilitch sobre seus poderes sobrenaturais contribuem para reforçar essa atmosfera. A própria Katierina confirma que ele gozava dessa fama: "Nossa gente o chamava de feiticeiro" (Dostoiévski, 2006, p. 93), diz ela.

No entanto, não há nada de irreal, de fantástico na novela. Tudo é perfeitamente explicável. E essa atmosfera que envolve a figura de Múrin, colocando Katierina como vítima de seu poder misterioso, aos poucos vai se dissipando aos olhos de Ordínov. No 
final, mesmo entregue à crença e ao misticismo, depois de derrotado no duelo pelo coração de Katierina, ele chega por si próprio à conclusão de que ela, ao contrário do que afirmava Múrin, "estava em seu perfeito juízo" (Dostoiévski, 2006, p. 117). Ele compreende que ser um "coração fraco" não era algo que estava em sua natureza, nas entranhas mesmas de seu ser, mas o resultado de "uma tirania profunda e implacável sobre uma pobre criatura indefesa" (Dostoiévski, 2006, p. 117). Percebe nitidamente que ela, em sua pureza, não podia ter consciência da tirania de que era vítima, de que "lisonjeavam astutamente a inclinação inexperiente de seu coração confuso e impetuoso", distorcendo-lhe a verdade, com o propósito de manter a sua cegueira.

Ou seja, as palavras de Múrin sobre Katierina, de que ela é "meio louca", de que "enlouqueceu", adquirem uma certa dose de verdade. O que ele se recusa a revelar, no entanto, é como e por que ela ficou assim. Ele diz a Ordínov: "Ela é meio louca! Por que e como enlouqueceu... para que você precisa saber?" (Dostoiévski, 2006, p. 111). Embora ele não diga, Ordínov acaba chegando por si mesmo à verdade. Ao dar-se conta de todo o processo empregado por Múrin para a "escravização" moral de Katierina, ele chega por si próprio à fórmula do "coração fraco", que expressa de maneira acabada o mesmo processo empregado para a alienação dos mais fracos pelos poderosos desse mundo.

E, assim, com a situação criada na novela, por meio da figura de Katierina, Dostoiévski mostra toda a violência que significa o poder de um indivíduo sobre outro, que só pode servir à satisfação das necessidades humanas mais abjetas. Mas mostra também, de forma simbólica, o estado de completa inércia e impotência em que se encontrava o intelectual progressista para lutar por seus ideais de justiça e liberdade.

Ainda que a ação esteja concentrada em apenas alguns dias, Dostoiévski apresenta a personagem Katierina numa perspectiva temporal que se revela fundamental. Trata-se do tempo que transcorre desde o momento em que ela, ao introduzir Ordínov em sua casa, acalenta a ilusão de que ele é seu "hóspede esperado" e de que a resgataria até o momento em que a ilusão é desfeita, quando ela se dá conta da real situação de seu 
"libertador" e da vanidade de suas esperanças.

Mas, para sermos justos com Ordínov, é preciso reconhecer que, se Katierina fica com o outro, isso se deve não apenas à impotência dele, mas também à dela própria para renunciar àquilo que a mantém cativa. Ou seja, num nível mais simbólico, "o povo, a alma russa", se recusa a "unir forças" com o "intelectual progressista, ocidentalista", não só por perceber sua impotência e incapacidade de lutar por seus objetivos, mas porque ele próprio não tem forças para renunciar àquilo que o mantém oprimido.

É questionável, portanto, a opinião de Leonid Grossman, de que não é "nem o tiro de Múrin, nem o punhal de Ordínov que conduzem ao desenlace. A própria heroína decide seu destino" (Grossman, 1962, p. 97). O que está em questão é justamente se ela tinha escolha; pois o que a novela acaba por trazer à tona, de forma viva e determinante, é a que ponto a sociedade, o meio, influencia na construção do indivíduo, define sua vida, seu comportamento e não lhe deixa alternativa.

Enfim, A Senhoria é a narrativa de uma situação que se revela de forma contraditória, naquilo que ela oculta. O método para a alienação da alma de Katierina, cuja essência se revela na capacidade de Múrin de inculcar nela a opinião de um bem que ela não possui (a liberdade), mostra-se tão eficiente, que ela continua a fazer planos para se despedir da vida que leva e de seu antigo amor e se dedicar a um novo, sem se dar conta absolutamente de que "as asas de sua alma livre e audaciosa" haviam sido podadas, tornando-a "incapacitada tanto de se rebelar como de se arrojar livremente para a verdadeira vida" (Dostoiévski, 2006, p. 117).

Essa abjeção extrema, que serve como símbolo grotesco para definir a situação humana revelada na novela, parece não se restringir apenas àquilo que está dado como objeto da narrativa. Ela se estende também ao próprio papel do narrador, que se manifesta na relação que ele estabelece com a narrativa. Ao se permitir penetrar na história apenas por meio da perspectiva de Ordínov, o narrador transpõe para a obra a ideia de que não sabe tudo, colocando-se na mesma situação que as demais personagens. Ou seja, ele não 
aparece como parte essencial de uma concepção de mundo, de vida, um deus que cria como quer. Mesmo o tom enigmático que ele escolhe para contar a história, e que espelha a própria modalidade da narrativa, poderia ser considerado na novela como reflexo da sua própria alienação.

Então, há na novela essa capa de sentido mais secreta, que só pôde ser configurada pela posição adotada pelo narrador. Ao se restringir ao campo de visão de Ordínov, a única personagem à qual ele se liga, deixa transparecer toda a limitação de sua capacidade de percepção, mostrando um grau de consciência literária que chega quase a explicitar uma visão altamente crítica sobre o seu papel e que o aproxima das próprias situações que ele criou.

O que está em questão em $A$ Senhoria, portanto, não é só a configuração de uma poética pela articulação dos elementos implícitos na narrativa, mas também uma atitude crítica do narrador em relação à sua própria arte. Com isso, Dostoiévski revela nessa obra um método crítico e uma estratégia literária tão consciente que, ainda que não tenham sido compreendidos, lhe permitiram atingir os mesmos objetivos dados aos escritores da tendência realista: a representação da realidade "tal como ela é".

\section{Referências bibliográficas}

Belínski, V. G. "Um Olhar para a Literatura Russa de 1847”. In: Sobrânie Sotchiniênii v

Triókh Tomakh (Obras reunidas em três volumes). V. III. Moscou: OGIZ, 1948.

Bem, A. L. "Dramatização do Delírio". In: Pesquisas. Cartas sobre Literatura. Moscou: Linguagens da Cultura Eslava, 2001.

Diláktorskaia, Olga. Peterbúrgskaia Pôviest Dostoiévskogo (A novela petersburguesa de Dostoiévski). Petersburgo: SSM, 1999.

Dostoiévski, F. M. Polnoe Sobrânie Sotchiniênii v Tridtsati Tomakh (Obras completas em 30 volumes) V. 21. Leningrado: Naúка, 1972. . A Senhoria. São Paulo: Editora 34, 2006. 
Ferreira, Aurélio Buarque de Holanda. Novo Dicionário da Língua Portuguesa. Rio de Janeiro: Nova Fronteira, $1^{\mathrm{a}}$ edição, $12^{\mathrm{a}}$ impressão.

Frank, Josef. As Sementes da Revolta, 1821-1849. São Paulo: Edusp, 1999.

Grossman, Leonid. Dostoiévski. Moscou: Molodáia Gvardia, 1962. . Put' Dostoiévskogo (O caminho de Dostoiévski). Leningrado: Izd. Brokgaus -

Efron.

Neuhauser, Rudolf. "The Landlady: A New Interpretation". In: Canadian Slavonic Papers, 10, 1968.

Terras, Victor. The Young Dostoevsky (1846-1849). Cтр. 196. Mouton, 1969. 